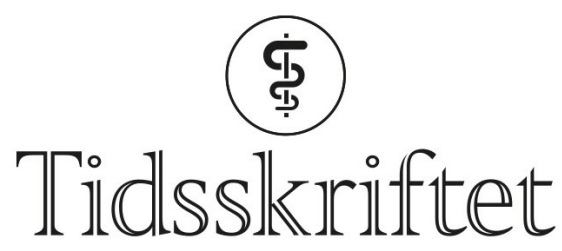

DEN NORSKE LEGEFORENING

\title{
Sult
}

FRA REDAKTØREN

\section{RAGNHILD ØRSTAVIK}

E-post: ragnhild.orstavik@tidsskriftet.no

Ragnhild Ørstavik er assisterende sjefredaktør i Tidsskriftet. Hun er dr.med. og har en bistilling som forsker ved Folkehelseinstituttet.

Det blir ingen gallamiddag når fredsprisen for 2020 skal feires i desember. Det er ikke det viktigste måltidet noen må hoppe over i år.

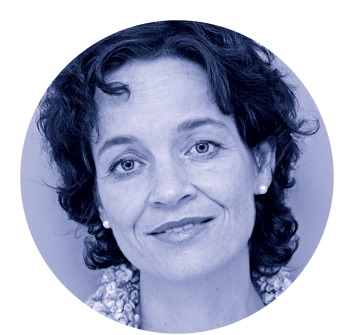

Foto: Einar Nilsen

I vår ende av verdens spisebord strever vi med en epidemi av overvekt. Men fremdeles finnes det mange rundt bordet som får for lite. Plassene de sitter ved, er rammet av krig og konflikt, klimaendringer og nå de helsemessige og økonomiske konsekvensene av en pandemi.

Nobels fredspris for 2020 gikk til Verdens matvareprogram. Dette er verdens største humanitære organisasjon. Den arbeider med matvare- og nødhjelp og med langsiktige prosjekter for å få til en bedre fordeling av verdens matvareressurser (1). Organisasjonen fikk prisen for sitt bidrag til å skape forutsetninger for fred i konfliktutsatte områder, for å være en pådriver i arbeidet mot bruken av sult som et våpen i krig og konflikt, og for sin innsats for å sørge for matforsyninger under den pågående pandemien (2). To tredjedeler av arbeidet foregår i land berørt av konflikter. Verdens matvareprogram arbeider også langsiktig, spesielt for å øke matsikkerheten til barn, og for å skape selvhjulpne og bærekraftige forhold for verdens 460 millioner småbønder.

Målet er å nå det andre av FNs 17 bærekraftsmål fra 2015, nemlig å helt utrydde sult innen 2030 (3). Det er langt igjen, og utviklingen går i feil retning. Fra begynnelsen av 20oo-tallet og frem til 2014 var det en nedgang i underernæring i verden. Deretter har utviklingen snudd. I 2019 sultet omkring 690 millioner mennesker, eller nærmere $9 \%$ av verdens innbyggere (3), og én av ti var rammet av manglende matvaresikkerhet (3). 47 millioner barn var underernærte.

I år blir det verre: Koronakrisen har ført til brå økonomisk nedgang, nedstengninger og proteksjonisme, og dermed redusert tilgang til mat. Samtidig sluker den akutte situasjonen 
ressurser som ellers skulle vært brukt til langsiktige prosjekter knyttet til ernæring, helse og utdanning. Foreløpige beregninger tyder på at ytterligere seks-syv millioner barn blir underernærte som en direkte konsekvens av pandemien (4). Forholdene er verst $\mathrm{i}$ krigsrammede områder: I Jemen, som FN har betegnet som verdens største humanitære krise, har det vært borgerkrig i fem år. Sykehus og vannforsyningsanlegg er bombet (5). Befolkningen har allerede gjennomgått epidemier med kolera og meslinger. Da er det kanskje ikke så rart at et nytt virus ikke føles så truende i seg selv: "Jeg er mer bekymret for matvareprisene enn for covid-19", uttalte en åttebarnsfar til Flyktninghjelpen i sommer (6). Jemen importerer 80-90\% av matvarene sine, og prisene hadde da allerede steget med $35 \%$.

De helsemessige konsekvensene av selv relativt kortvarig matmangel kan være store, især for ufødte og små barn

De helsemessige konsekvensene av selv relativt kortvarig matmangel kan være store, især for ufødte og små barn. Det vet vi fra tidligere, plutselige sultkatastrofer: Blokaden av de vestlige områdene av Nederland høsten 1944 førte til en rask og dramatisk nedgang i matforsyningene, som ble reversert omtrent like raskt da freden kom i mai året etter. Rasjoneringene var nede i 40o-8oo kilokalorier per dag. En slik dokumentert og tidsbegrenset nedgang i kaloriinntak kombinert med et (tross alt) velfungerende helsevesen og etterfølgende normaltilstand ga grunnlaget for "The Dutch Famine Study» (7). Gjennom den har man kunnet følge personer som var i ulike stadier av fosterutviklingen under blokaden (7). Resultatene viser at underernæring i fosterlivet fører til økt risiko for en hel rekke sykdommer, spesielt overvekt, diabetes og hjertesykdommer, men antakelig også alvorlige psykiske lidelser (7). Også de aller første årene av et barns liv er kritiske. Dårlig ernæring i denne perioden kan påvirke kognitiv utvikling, og dermed senere utdanningsmuligheter og det som samlet betegnes human kapital (8). Dette er enda en grunn til at tiltak som skal hjelpe de sultrammede under covid-19-pandemien, rettes mot kvinner i fertil alder og barn (9).

Verdens matvareprogram er fullfinansiert av donasjoner. I år har organisasjonen som mål å hjelpe 138 millioner mennesker - 41 millioner flere enn i 2019. Da trenger den 4,9 milliarder dollar i tillegg til den finansieringen den allerede har (10). Det kan være vel anvendte penger. Matvareprogrammets leder, David Beasley, uttalte i sommer at mat kan være den beste vaksinen mot kaos. Enda mer opplagt er det at mat er den beste vaksinen mot langsiktige konsekvenser av en akutt matvarekrise.

\section{LITTERATUR:}

1. United Nations. World Food Programme. https://www.wfp.org/overview Lest 25.10.2010.

2. The Nobel Prize. Nobels Fredspris for 2020.

https://www.nobelprize.org/prizes/peace/2020/161316-press-release-norwegian/ Lest 9.11.2020.

3. In Brief to The State of Food Security and Nutrition in the World 2020. Transforming food systems for affordable healthy diets. Rome: FAO, IFAD, UNICEF, WFP, WHO, 2020. Lest 9.11.2020.

4. Headey D, Heidkamp R, Osendarp S et al. Impacts of COVID-19 on childhood malnutrition and nutrition-related mortality. Lancet 2020;396: 519-21. [PubMed][CrossRef]

5. Mohareb AM, Ivers LC. Disease and famine as weapons of war in Yemen. N Engl J Med 2019;380: 109-11. [PubMed][CrossRef]

6. Norwegian Refugee Council. Yemen: Hunger crisis accelerating under Covid-19. https://www.nrc.no/news/2020/july/yemen-hunger-crisis-accelerating-under-covid-19/ Lest 24.10.2020.

7. Roseboom TJ. Epidemiological evidence for the developmental origins of health and disease: effects of prenatal undernutrition in humans. J Endocrinol 2019; 242: T135-44. [PubMed][CrossRef]

8. Martorell R. Improved nutrition in the first 1000 days and adult human capital and health. Am J Hum Biol 2017; 29: e22952. [PubMed][CrossRef] 
9. Fore HH, Dongyu Q Beasley DM et al. Child malnutrition and COVID-19: the time to act is now. Lancet 2020;396: 517-8. [PubMed][CrossRef]

10. Kuehn BM. Pandemic accelerates the threat of global hunger. JAMA 2020;324: 1489.

[PubMed][CrossRef]

Publisert: 23. november 2020. Tidsskr Nor Legeforen. DOI:10.4045/tidsskr.20.0910

C Tidsskrift for Den norske legeforening 2020. Lastet ned fra tidsskriftet.no 